\title{
PEMBIASAAN KEGIATAN KEAGAMAAN DALAM MEMBENTUK KARAKTER RELIGIUS DI MADRASAH
}

\author{
Dewi Hariyani \\ Institut Agama Islam Negeri Jember \\ dewihariyani89@gmail.com \\ Ainur Rafik \\ Institut Agama Islam Negeri Jember \\ ainurrafik64@gmail.com
}

DOI : 10.35719/adabiyah.v2i1.72

\begin{abstract}
Abstrak
Membentuk kepribadian anak memiliki moral yang baik sangat penting. Apalagi di zaman sekarang, di mana semuanya serba canggih. Namun disisi lain kemajuan teknologi juga memiliki dampak negatif dan dianggap sebagai salah satu faktor yang mempengaruhi menurunnya semangat anak untuk belajar dan beribadah. Guna menanggulangi permasalahan tersebut, MA Darul Hikam Kertonegoro Jenggawah Jember untuk menerapkan pembiasaan kegiatan keagamaan dalam rangka membentuk karakter religius. Tujuan penelitian ini adalah mendeskripsikan pembiasaan kegiatan keagamaan dalam membentuk karakter religius. Penelian ini menggunakan pendekatan kualitatif dengan jenis field research. Teknik pengumpulan data menggunakan observasi, wawancara dan dokumentasi. Analisis data menggunakan model interaktif Miles, Huberman dan Saldana. Keabsahan data menggunakan triangulasi sumber dan teknik. Hasil penelitian ini adalah 1) pembiasaan sholat dhuha dalam membentuk karakter religius yaitu membiasakan siswa tepat waktu, berjama'ah, dan khusyuk dalam beribadah; 2) pembiasaan kegiatan pembacaan asmaul husna dalam membentuk karakter religius membiasakan siswa untuk berdzikir serta membiasakan siswa untuk disiplin dan tanggung jawab dalam menghafal nama-nama Allah; 3) pembiasaan kegiatan khotmil Qur'an dalam membentuk karakter religius yaitu saling bekerjasama dalam mengkhatamkan Al-Qur'an serta membiasakan siswa untuk selalu membaca Al-Qur'an; 4) pembiasaan kegiatan pembelajaran terjemah Al-Qur'an dalam membentuk karakter religius yaitu membiasakan siswa untuk lebih cermat, seksama serta sungguh-sungguh dalam menerjemah Al-Qur'an sehingga mampu memahami kitab Allah dan mampu memperbaiki tingkah lakunya dalam kehidupan sehari-hari.
\end{abstract}

Kata Kunci: pembiasaan kegiatan keagamaan, karakter religius

\begin{abstract}
Forming a child's personality to have good morals is very important. Moreover, in this day and age everything is very sophisticated and it easily influences children to leave the obligation to study and do activities like a Muslim. Overcoming these problems MA darul hikam Kertonegoro Jenggawah Jember implements the habituation of religious activities in shaping religious character. This study uses a qualitative approach with
\end{abstract}


the type of research file. data collection techniques using observation, interviews, and documentation. Data analysis using interactive models of miles, huberman, and saldana. The validity of the data used source and technique triangulation. The results of this study are 1) the habituation of Duha prayer in forming religious characters, namely accustoming students to being on time, in congregation and being devoted to worship, 2) habituation of reading Asmaul Husna in forming religious characters accustom students to dzikir and accustom students to discipline and responsibility in memorizing the names of Allah, 3) habituation of Qur'anic khotmil activities in shaping religious character, namely working together in understanding the Koran and accustoming students to always reading the Qur'an, 4) habituation of learning activities to translate the Qur'an in forming religious characters, namely accustom students to be more careful and earnest in translating the Qur'an so that they are able to understand the book of Allah and be able to improve their behavior in everyday life.

Keywords: habituation of religious activities, religious character

\section{Pendahuluan}

Berdasarkan Undang-Undang RI Nomor 20 Tahun 2003 tentang Sistem Pendidikan Nasional yang merumuskan tujuan pendidikan nasional yaitu mencerminkan gambaran umum sosok manusia Indonesia yang diharapkan dan harus dihasilkan melalui penyelenggaraan setiap program pendidikan. sehingga, rumusan tujuan pendidikan nasional menjadi dasar dalam pengembangan nilainilai budaya karakter bangsa di sekolah yang berlandaskan pada Pancasila, UUD 1945 dan kebudayaan bangsa Indonesia.

Pendidikan karakter menjadi isu yang sangat hangat diperbincangkan mulai dari diberlakukannya pendidikan secara nasional di semua jenjang pendidikan yang diawali dari tingkat sekolah dasar. Pendidikan karakter menjadi sesuatu yang sangat penting untuk membentuk generasi yang berkualitas. Sesuai dengan pernyataan E.Mulyasa dalam jurnal (Atika, 2014) yang menyatakan bahwasanya pendidikan karakter bertujuan meningkatkan mutu proses dan hasil pendidikan yang mengarah pada pembentukan karakter dan akhlak mulia peserta didik secara utuh, terpadu, dan seimbang, sesuai dengan standar kompetensi lulusan pada setiap satuan pendidikan.

Nurul Zuhriyah dalam jurnal (Andri \& Johan, 2017) menyatakan bahwa pendidikan karakter sama dengan pendidikan budi pekerti. Dimana tujuan budi pekerti adalah untuk mengembangkan watak atau tabi'at siswa dengan cara menghayati nilai-nilai keyakinan masyarakat sebagai kekuatan moral hidupnya melalui kejujuran, dapat dipercaya, dan kerjasama yang menekankan ranah efektif (perasaan, sikap) tanpa meninggal kan ranah kognitif (berfikir rasional) dan ranah 


\section{AL-ADABIYAH: Jurnal Pendidikan Agama Islam}

psikomotorik (keterampilan, terampil mengolah data, mengemukakan pendapat dan kerjasama). Seseorang dapat dikatakan berkarakter atau berwatak jika telah berhasil menyerap nilai dan keyakinan yang dikehendaki masyarakat serta digunakan sebagai kekuatan dalam hidupnya.

Membentuk kepribadian anak yang cerdas, pandai, memiliki perilaku atau moral yang baik, selalu mengingatkan Allah SWT dimanapun mereka berada dan selalu mengingat tentang kewajiban yang harus dilakukan itupun tidaklah mudah. Apalagi di zaman sekarang yang semuanya serba canggih sehingga dengan mudahnya mempengaruhi anak-anak yang masih labil untuk meninggalkan kewajibannya. Dengan adanya hal tersebut pendidik tidak akan tinggal diam melihat anak didiknya rusak akan pengaruh kemajuan zaman. Untuk itu banyak sekolah-sekolah yang memiliki program- program religius disekolah.

Dalam Kamus Besar Besar Bahasa Indonesia, kegiatan adalah kekuatan atau ketangkasan (dalam berusaha). Sedangkan pengertian keagamaan berasal dari agama yang mendapat awalan "ke-“ dan "-an" sehingga membentuk kata baru yaitu "keagamaan". Jadi keagamaan mempunyai arti yang berhubungan dengan agama yaitu dengan sebuah keimanan dan keyakinan (Depdiknas, 2008: 15). Jadi dapat disimpulkan kegiatan keagamaan adalah aktivitas kegiatan keagamaan yang berhubungan dengan agama dan ditunjukkan dalam bentuk praktek agama seperti sholat dhuha, pembacaan asmaul husna, khatmil Qur'an dan pembelajaran terjemah Al-Qur'an.

Hal ini sesuai dengan penelitian yang telah dilakukan oleh Imro'atul Hasanah dengan judul "Implementasi Metode Pembiasaan Keagamaan Dalam Membentuk Karakter Religius Siswa Di Mts Nu Darussalam Ngadirgo Mijen Semarang." Menunjukkan hasil penelitiannya yaitu implementasi metode pembiasaannya meliputi pembiasaan dalam akhlak meliputi 3S (Senyum, Sapa, Salam) dan hidup bersih, serta pembiasaan dalam ibadah meliputi do'a harian, membaca asmaul husna, baca tulis Al-Qur'an, hafalan surat-surat pendek, istighosah dan sholat dhuhur berjama'ah (Latifah, 2018).

MA Darul Hikam Kertonegoro Jenggawah Jember merupakan salah satu sekolah yang menerapkan kegiatan-kegiatan keagamaan dalam membantu membentuk karakter religius. Selain itu, belum tentu sekolah lain menerapkan kegiatan-kegiatan keagamaan tersebut. MA Darul Hikam Kertonegoro Jenggawah Jember yang memiliki berbagai kegiatan keagamaan yang menarik serta mendidik diantaranya yaitu pembiasaan sholat dhuha, pembacaan asmaul husna, khatmil 


\section{AL-ADABIYAH: Jurnal Pendidikan Agama Islam}

Qur'an dan pembelajaran terjemah Al-Qur'an dengan menggunakan metode PPTQ Safinda. Perbedaan kajian peneliti dengan penelitian terdahulu yaitu terdapat pada fokus penelitiannya, disini peneliti lebih berfokus kepada pelaksanaan kegiatan keagamaan seperti sholat dhuha, pembacaan asmaul husna, khotmil Qur'an dan pembelajaran terjemah Al-Qur'an dalam membentuk karakter religius.

Adapun tujuan penelitian ini adalah mendeskripsikan pembiasaan kegiatan sholat dhuha dalam membentuk karakter religius di Madrasah Aliyah Darul Hikam Kertonegoro Jenggawah Jember, mendeskripsikan pembiasaan kegiatan pembacaan asmaul husna dalam membentuk karakter religius di Madrasah Aliyah Darul Hikam Kertonegoro Jenggawah Jember, mendeskripsikan pembiasaan kegiatan khatmil Qur'an dalam membentuk karakter religius di Madrasah Aliyah Darul Hikam Kertonegoro Jenggawah Jember, mendeskripsikan pembiasaan kegiatan pembelajaran terjemah Al-Qur'an dalam membentuk karakter religius di Madrasah Aliyah Darul Hikam Kertonegoro Jenggawah Jember.

\section{Tinjauan Literatur}

\section{Kegiatan Keagamaan di Sekolah}

Dalam Kamus Besar Besar Bahasa Indonesia, kegiatan adalah kekuatan atau ketangkasan (dalam berusaha). Sedangkan pengertian keagamaan berasal dari agama yang mendapat awalan "ke-“ dan "-an" sehingga membentuk kata baru yaitu "keagamaan". Jadi keagamaan mempunyai arti yang berhubungan dengan agama yaitu dengan sebuah keimanan dan keyakinan (Depdiknas, 2008, hal. 15).

Dari pengertian diatas dapat disimpulkan bahwasanya kegiatan keagamaan di sekolah adalah rancangan sejumlah aktifitas yang berhubungan dengan keagamaan yang dilaksanakan atau direncanakan secara berulangulang. Aktivitas keagamaan yang akan penulis bahas dalam penelitian ini adalah sholat dhuha, pembacaan asmaul husna, khotmil Qur'an dan pembelajaran terjemah Al-Qur'an.

a. Sholat Dhuha

1) pelaksanaan sholat dhuha

Dalam pelaksanaan kegiatan sholat itu sendiri ada beberapa karakter positif yang dibentuk diantaranya yaitu: 
a) Ketepatan waktu

Sholat dapat dijadikan media untuk melatih kebiasaan tepat waktu. Manfaat bila mental "tepat waktu" itu terbangun dengan baik. Misalnya, pekerjaan-pekerjaan penting meski tak mendesak bisa cepet selesai dikerjakan. Dengan begitu kita segera bisa melakukan hal-hal lain yang dianggap perlu. Lebih lagi dengan mental "tepat waktu" pekerjaan lain bisa diselesaikan lebih awal bahkan jauh dari target waktu yang ditentukan.

b) Kebersamaan

Sholat dapat dijadikan media dalam membentuk kooperatif. Ini berkaitan dengan team-work. Artinya, orang yang biasa sholat berjamaah memiliki kebiasaan hidup mengutamakan kepentingan bersama.

c) Kekhusyu'an

Sholat dapat dijadikan media untuk melatih fokus. Dalam sholat, istilah ini dikenal dengan khusyu'. Sholat adalah media yang sangat baik, mudah, praktis serta efisien untuk melatih kekhusyu'an (fokus) itu. Sholat sebenarnya sudah "tersedia" dalam bentuk gerakan dan bacaan dari sstu langkah ke langkah berkutnya secara tertib. Langkah-langkah itulah yang kalau disadari, sebenarnya memberi jalan keluar bagi kita untuk (khusyu') (Rosidatun, 2018: 49-51).

b. Pembacaan Asmaul Husna

1) Pelaksanaan pembacaan asmaul husna

Dengan kegiatan Berdzikir asmaul husna tersebut diharapkan akan membentuk karakter yang positif kepada yang mengikuti kegiatan tersebut, terutama seperti yang diungkapkan oleh Ary Ginanjar dalam bukunya Mulyasa yang menyatakan:

"Bahwa setiap karakter positif sesungguhnya akan merujuk kepada sifat-sifat mulia Allah, yaitu Al-Asma' al-Husna. Sifat-sifat dan nama-nama mulia ini merupakan sumber inspirasi setiap karakter positif yang dirumuskan oleh siapapun. Dari sekian banyak karakter yang bisa diteladani dari nama-nama Allah itu, terangkan dalam 7 (tujuh) karakter, yaitu jujur, tanggungjawab, disiplin, visioner, adil, peduli dan kerjasama." (Prasetyo, 2017) 


\section{AL-ADABIYAH: Jurnal Pendidikan Agama Islam}

2) Pentingnya pembacaan asmaul husna

Pentingnya kegiatan pembacaan asmaul husna itu terdapat beberapa alasan utama diantaranya sebagai berikut:

a) Lebih mengenal Allah. Dengan kita mengenal serta memahami namanama serta sifat-sifat Allah, maka kita sebagai seorang hamba tentu akan bertambah kecintaan kita kepada Allah, selalu berusaha serta tawakal ketika berbuat dosa.

b) Hidup akan terkondisikan untuk beribadah. Memahami Allah dengan mengenal nama-nama serta sifat-Nya merupakan salah satu dasar keimanan seorang hamba. Dengan ini maka keimanan seorang hamba meningkat. Ketika keimanan meningkat, maka ia semakin rajin dalam beribadah kepada Allah.

c) ilmu mengenai sifat-sifat Allah merupakan ilmu yang paling mulia, serta paling utama. Ilmu ini memiliki tempat kedudukan yang agung serta derajatnya paling tinggi (Ramadan, 2019, hal. 89-90).

c. Khatmil Qur'an

1)Pelaksanaan khotmil Qur'an

Dalam pelaksanaan kegiatan khatmil Qur'an ada beberapa karakter positif yang dapat dibangun diantaranya yaitu sebagai berikut:

a) Kerjasama

Kerjasama merupakan sifat social, bagian dari kehidupan masyarakat yang tidak dapat dielakkan oleh manusia dalam kehidupan sehari-hari (Wulandari, et al, 2015). Kerjasama bukan berarti manusia tidak dapat mandiri, sebab manusia memiliki keterbatasan kemampuan. Dengan kerjasama, keterbatasan tersebut dapat diisi oleh kemampuan oranglain dan berorganisasi untuk mencapai tujuan. Sebagaimana yang diutarakan oleh Soerjono Soekanto, yang menyatakan bahwa kerjasama merupakan suatu usaha bersama antara orang perorangan atau kelompok untuk mencapai tujuan tertentu. Definisi tersebut dapat dimaknai bahwa setiap individu atau kelompok dapat berinteraksi untuk mencapai tujuan bersama (Efendi, 2018).

b) Ketekunan

Tekun adalah salah satu prinsip dasar sukses. Dengan tetap memupuk "sifat tekun", jika tidak bisa mencapai sasaran sesuai target 
waktu, maka tidak akan merasakan yang namanya kegagalan, sebaliknya akan berusaha mencari dan menemukan cara atau jalan lain untuk tetap menuju sasaran sukses. Dalam hal ini maksudnya yaitu tidak akan berhenti terlalu lama, tetapi memikirkan cara-cara baru yang sekiranya lebih memungkinkan untuk bisa sampai pada garis finish. (Wuryanano, 2004: 75).

d. Pembelajaran Terjemah Al-Qur'an

1)Pelaksanaan pembelajaran terjemah Al-Qur'an

Dalam pelaksanaan pembelajaran terjemah Al-Qur'an ada beberapa karakter positif yang dapat dibentuk diantaranya:

a) Kesungguhan

Kesungguhan yaitu kemauan remaja muslim untuk komit (sungguh-sungguh) dalam ketaatan. Hal ini di dahului dengan perjuangan panjang dan berat, dengan memobilitasi motivasi-motivasi iman dalam jiwa, siap menolak dorongan hawa nafsu dan syahwat keduniaan yang selalu berusaha dibangkitkan oleh setan. Tanpa adanya kesungguhan maka akan memperoleh hasil yang kurang memuaskan. Selain itu akan banyak waktu yang terbuang sia-sia. Sebaliknya, jika melakukan sesuatu pekerjaan dengan sungguhsungguh serta tekun akan memperoleh hasil yang maksimal dan penggunaan waktunya lebih efektif. Meskipun seseorang itu sudah memiliki kematangan, kesiapan serta mempunyai tujuan yang konkret, tetapi tidak sungguh-sungguh, hanya sebagai penggugur kewajiban, akibatnya akan memperoleh hasil yang kirang memuaskan (Dalyono, 2010: 53-54).

b) Ketelitian

Menurut Ashari Teliti berarti cermat dan saksama dalam menjalankan sesuatu. Orang yang teliti ditunjukkan dengan cermat, penuh minat, dan berhati-hati dalam menjalankan sesuatu agar tidak terjadi kesalahan, dan mendapatkan hasil yang baik (Koesworo, 2018). Ketelitian dalam mengerjakan segala hal mutlak diperlukan. Hal tersebut dikarenakan sudah menjadi sunnatullah jika manusia adalah tempatnya salah dan lupa. 
2) Kemampuan yang di dapat siswa dalam pembelajaran Al-Qur'an

Menurut Tim Perumus dalam bukunya yang berjudul "metodologi pengajaran agama" yang dikutip oleh Sri Belia Harahap menyatakan dalam proses pembelajaran Al-Qur'an memiliki tujuan sebagai berikut yaitu memberikan pengetahuan Al-Quran kepada anak yang mampu mengarahkan kepada:

a) Kemantapan membaca sesuai dengan syarat-syarat yang telah ditetapkan dan menghafal ayat-ayat atau surat-surat yang mudah bagi mereka

b) Kemampuan memahami kitab Allah secara sempurna, memuaskan akal dan mampu menenangkan jiwanya

c) Kesanggupan menerapkan ajaran Islam dan menyelesaikan problema hidup sehari-hari

d) Kemampuan memperbaiki tingkah laku murid melalui metode pengajaran yang tepat

e) Kemampuan memanifestasikan keindahan retorika dan uslub AlQur'an

f) Penumbuhan rasa cinta dan keagungan Al-Qur'an dalam jiwanya

g) Pembinaan pendidikan Islam berdasarkan sumber-sumbernya yang utama dari Al-Qur'an (Harahap, 2020: 16).

\section{Bentuk-bentuk Karakter Religius}

Menurut Agus Wibowo, karakter religius diartikan sebagai sikap atau perilaku yang patuh dalam melaksanakan ajaran agama yang dianutnya, toleran terhadap pelaksanaan ibadah, dan hidup rukun dengan sesama (Wibowo, 2012: 26).

Menurut Asmaun Sahlan, karakter religius adalah sikap yang mencerminkan tumbuh kembangnya kehidupan beragama yang terdiri dari tiga unsur pokok yaitu aqidah, akhlah dan ibadah yang menjadi pedoman perilaku sesuai dengan aturan-aturan ilahi untuk mencapai kesejahteraan serta kebahagiaan hidup didunia dan akhirat (Sahlan, 2012: 4).

Berdasarkan pendapat diatas, dapat disimpulkan bahwa karakter religius adalah sikap yang patuh dalam melaksanakan ajaran agama yang dianutnya, toleran terhadap pelaksanaan ibadah, dan hidup rukun dengan sesama. Macam-macam nilai religius menurut Fathurrahman (2015) yaitu sebagai berikut: 

a. Nilai Ibadah
b. Nilai Ruhul Jihad
c. Nilai akhlak dan kedisipilan
d. Nilai Keteladanan
e. Nilai Amanah dan ikhlas

Sementara itu menurut Novan Ardy Wiyani mengemukakan system nilai religius adalah ajaran Islam yang bersumber dari Al-Qur'an dan hadits serta ijtihad sebagai model berfikir islami (Wiyani, 2018, hal. 21-22).

Nilai-nilai pendidikan karakter religius

\begin{tabular}{|c|l|}
\hline $\begin{array}{c}\text { Ruang lingkup karakter dalam } \\
\text { pandangan Islam }\end{array}$ & \multicolumn{1}{|c|}{$\begin{array}{c}\text { Nilai-nilai pendidikan karakter } \\
\text { dalam pandangan Islam }\end{array}$} \\
\hline Hubungan manusia dengan & 1. Patuh \\
Allah SWT & 2. Menerima konsekuensi \\
& 3. Ikhlas \\
& 4. Optimis \\
& 5. Bekerja keras \\
& 6. Bertanggung jawab \\
& 7. Kesadaran diri \\
& 8. Intropeksi diri \\
\hline Hubungan manusia dengan diri & 1. Jujur \\
& 2. Bertanggung jawab \\
sendiri & 3. Konsisten \\
& 4. Mandiri \\
& 5. Disiplin \\
& 6. Bekerja keras \\
& 7. Percaya diri \\
& 8. Lapang dada \\
\hline Hubungan manusia dengan & 1.Jujur \\
manusia lain & 2. Dapat dipercaya \\
& 3. Konsisten \\
& 4. Pemberani \\
& 5. Bekerja keras \\
& 6. Ramah \\
& 7. Kasih saying \\
\hline Hubungan manusia dengan alam & 1. Mencintai kebersihan \\
& 2. Menyayangi binatang \\
& 4. Menjaga tumbuhan \\
& 4. Menjaga kelestarian alam \\
\hline
\end{tabular}

\section{Metode}

Pendekatan yang digunakan dalam penelitian ini menggunakan adalah pendekatan kualitatif (Margono, 2010: 15). Menurut Bogdan Dan Taylor dalam bukunya (Moeleong, 2017: 4) menyatakan bahwasanya metodologi kualitatif 


\section{AL-ADABIYAH: Jurnal Pendidikan Agama Islam}

sebagai prosedur penelitian yang menghasilkan data deskriptif berupa kata-kata tertulis atau lisan dari orang-orang dan perilaku yang dapat diamati. Jenis penelitian yang digunakan adalah field research yaitu tindakan penelitian yang secara langsung mengadakan pengamatan untuk memperoleh informasi yang diperlukan baik itu dikantor-kantor, rumah-rumah sakit, panti-panti asuhan, sekolah-sekolah dan sebagainya (Bungaran \& sosrodiharjo, 2014: 13). Dalam hal ini peneliti melakukan penelitian secara langsung di sekolah menengah atas tepatnya di MA Darul Hikam desa Kertonegoro kecamatan Jenggawah untuk melakukan kegiatan penelitian.

Penentuan subyek dalam penelitian ini dengan cara purposive, yaitu teknik pemilihan sumber data dengan pertimbangan dan tujuan tertentu. Pertimbangan tertentu misalnya orang tersebut dianggap paling tahu apa yang diharapkan oleh peneliti (Sugiyono, 2016: 216). Teknik pengumpulan data yang digunakan yaitu wawancara, observasi dan dokumentasi. Wawancara yang digunakan dalam penelitian ini adalah wawancara semi terstruktur, tujuan dari wawancara jenis ini adalah untuk menemukan permasalahan secara terbuka, dimana pihak yang diajak wawancara diminta pendapat dan ide-idenya (Sugiyono, 2016: 233). Observasi merupakan sebuah tekhnik pengumpulan data yang mengharuskan peneliti turun ke lapangan mengamati hal-hal yang berkaitan dengan ruang, tempat, pelaku, kegiatan, benda-benda, waktu, peristiwa, tujuan dan perasaan (Sugiyono, 2016: 224). Dalam hal ini peneliti datang di tempat kegiatan orang yang diamati, tetapi tidak ikut terlibat dalam kegiatan yaitu dengan observasi partisipasi pasif (Ghony \& Fauzan, 2012: 165). Dokumentasi merupakan catatan peristiwa yang sudah berlalu. Dokumentasi bisa berbentuk tulisan, gambar, atau karyakarya monumental dari seseorang (Sugiyono, 2016: 240). Teknik analisis datanya menggunakan teori interaktif Miles, Huberman dan Saldana yaitu Kondensasi Data (data condensation), menyajikan data (data display), dan menarik simpulan atau verifikasi (conclusion drawing and verification) (Miles et al, 2014: 12).

\section{Hasil dan Pembahasan}

\section{Pembiasaan kegiatan sholat dhuha dalam membentuk karakter religius di MA Darul Hikam Kertonegoro, Jenggawah, Jember}

Membentuk kepribadian anak yang cerdas, pandai, memiliki perilaku atau moral yang baik, setelah mengingat Allah swt dimanapun mereka berada dan selalu mengingat tentang kewajiban yang harus dilakukan itupun tidaklah 


\section{AL-ADABIYAH: Jurnal Pendidikan Agama Islam}

mudah. Apalagi di zaman sekarang yang semuanya serba canggih dengan sangat mudah untuk mempengaruhi anak-anak zaman sekarang yang masih labil, sangat mudah menarik simpatik anak sehingga anak dengan mudahnya meninggalkan kewajibannya untuk belajar dan melakukan kewajibankewajiban sebagai seorang muslim. Tetapi pendidik juga tidak akan tinggal diam begitu saja melihat anak didiknya rusak akan pengaruh kemajuan zaman. Maka dari itu upaya yang dilakukan oleh MA Darul Hikam Kertonegoro, Jenggawah, Jember dalam membentuk karakter religius siswa yaitu melalui pembiasaan kegiatan keagamaan salah satunya yaitu pembiasaan kegiatan sholat dhuha.

Guru MA Darul Hikam Kertonegoro, Jenggawah, Jember menerapkan pembiasaan sholat dhuha guna mendidik para siswanya agar menjadi anak yang taat dalam beribadah serta patuh dalam menjalankan perintah Allah khususnya ibadah sholat karena sholat merupakan rukun islam yang kedua dan wajib dikerjakan oleh setiap orang yang beragama Islam. Oleh karana itu kegiatan sholat dhuha ini rutin dilaksanakan setiap hari jum'at sebelum pembelajaran dimulai.

Temuan ini sesuai dengan pendapatnya Muhammad Fathurrahman dalam bukunya (Fathurrahman, 2015: 6) yang mengatakan bahwa Ibadah adalah ketaatan manusia kepada Tuhan yang diimplementasikan dalam kegiatan sehari-hari misalnya shola, puasa, zakat dan lain sebagainya. Nilai ibadah perlu ditanamkan kepada diri seseorang anak didik, agar anak didik menyadari pentingnya beribadah kepada Allah.

Dibentuknya program pembiasaan sholat dhuha adalah untuk membentuk karakter religius siswa. Sesuai hasil temuan peneliti di MA darul Hikam yang diperoleh melalui wawancara, observasi dan dokumentasi dapat diketahui pembentukan karakter religius melalui kegiatan sholat dhuha diantaranya:

a. Tepat waktu dalam menunaikan ibadah kepada Allah agar terhindar dari sikap keji dan mungkar

Di MA Darul Hikam siswa dibiasakan untuk melakukan sholat dhuha tepat waktu sekitar jam 06.15. dengan diberlakukan aturan seperti itu mental anak terbentuk dengan baik seperti halnya mereka dapat mengerjakan sesuatu dengan cepat tepat, lebih lagi dengan mental tepat waktu pekerjaan lain bisa diselesaikan lebih awal. Dengan diadakannya 


\section{AL-ADABIYAH: Jurnal Pendidikan Agama Islam}

kegiatan sholat dhuha secara tepat waktu, siswa akan terbiasa sholat tepat pada waktunya baik itu sholat sunnah maupun sholat wajib sehingga siswapun terhindar dari sikap keji dan mungkar. Pernyataan ini sesuai dengan tujuan dilaksanakan kegiatan sholat dhuha yang telah peneliti paparkan di bab dua, dengan firman Allah yang terdapat dalam surah AlAnkabut ayat 45 yang berbunyi:

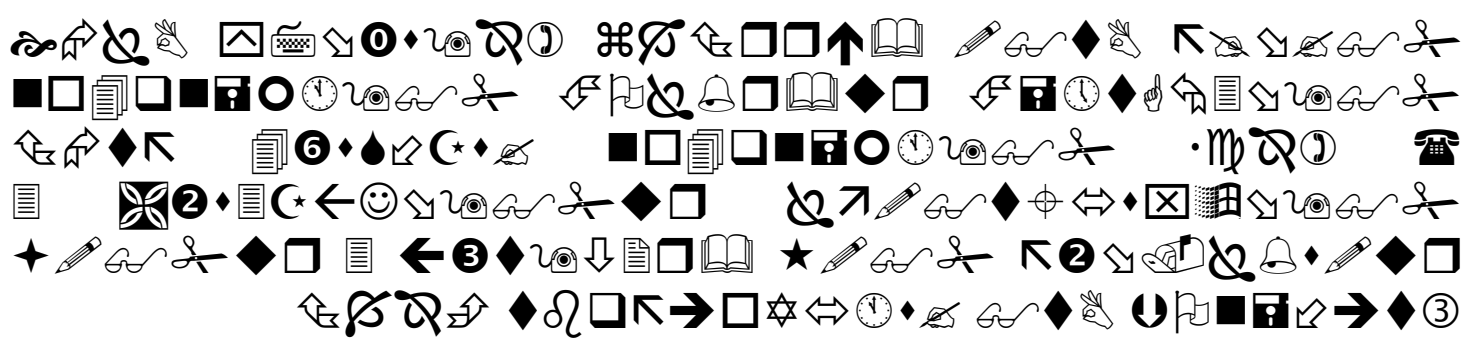

Artinya:"Bacalah apa yang telah diwahyukan kepadamu, Yaitu Al-Kitab

(Al-Quran) dan dirikanlah shalat. Sesungguhnya shalat itu mencegah dari (perbuatan- perbuatan) keji dan mungkar. Dan Sesungguhnya mengingat Allah (shalat) adalah lebih besar (keutamaannya dari ibadah-ibadah yang lain). dan Allah mengetahui apa yang kamu kerjakan." (Q.S. Al-Ankabut/29 : 45).

Kesimpulan dari ayat diatas yaitu salat satu alasan dilaksanakannya sholat adalah seseorang mampu mengendalikan diri sehingga tidak melakukan perbuatan keji dan munkar, serta perbuatan yang dapat merugikan diri sendiri dan orang lain. Pengendalian diri ini akan memunculkan suatu perilaku yang mulia bagi lingkungan dan orang-orang sekitar.

b. Kegiatan sholat dhuha dilaksanakan secara berjama'ah untuk menciptakan kebersamaan siswa

Pembiasaan kegiatan sholat dhuha di MA Darul Hikam dilaksanakan secara berjama'ah yang diimami langsung oleh pemilik yayasan/kepala sekolah. Siswa dibiasakan untuk melakukan sholat secara berjama'ah agar memiliki kebiasaan hidup dengan mengutamakan kepentingan bersama, dan untuk menjalin komunikasi dan silaturahmi yang baik antar siswa. Hal ini sesuai dengan penjelasan Rosidatun sholat dapat djadikan media dalam membentuk kooperatif. Ini berkaitan dengan team-work. Artinya, orang yang biasa sholat berjamaah memiliki kebiasaan hidup mengutamakan kepentingan bersama (Rosidatun, 2018: 50-51). 


\section{AL-ADABIYAH: Jurnal Pendidikan Agama Islam}

c. Kegiatan sholat dhuha melatih kefokusan agar siswa lebih khusyuk dalam melaksanakan ibadah kepada Allah sehingga dapat menimbulkan perasaan tenang, damai dan tentram

Dalam kegiatan sholat di MA Darul Hikam di masjid yang luas dan antara putra dan putri dibatasi dengan tirai, dan bagi siswa yang berhalangan berada di luar masjid dan untuk situasinya dikondisikan oleh osis yang bertugas agar pelaksanaan kegiatan sholat dhuha dapat berjalan dengan khidmat dam khusyuk serta agar siswa yang tidak mengikuti sholat tidak ramai, sehingga sholat dhuha bisa dilaksanakan dengan rasa tenang, dan menunduk karena merasa rendah kepada Allah. Temuan sesuai dengan firman Allah dalam surah ayat 28 yang berbunyi:

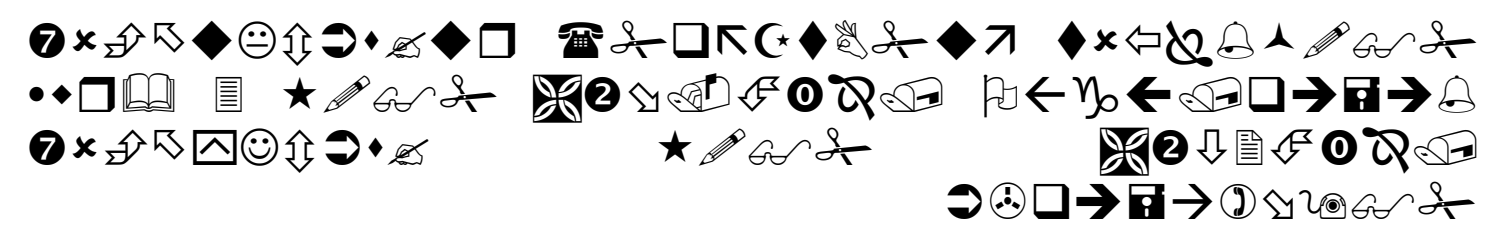

Artinya: "(yaitu) orang-orang yang beriman dan hati mereka manjadi tenteram dengan mengingat Allah. Ingatlah, hanya mengingat Allahlah hati menjadi tenteram.”.(Q.S. ar-Ra`d/13: 28)

Dengan diawali kegiatan shalat dhuha dipagi hari, siswa diberi kemudahan dan kelancaran dalam menjalankan aktifitas kehidupah seharihari terutama ketika sedang menuntut ilmu.

\section{Pembiasaan kegiatan pembacaan asmaul husna dalam membentuk karakter religius di MA Darul Hikam Kertonegoro, Jenggawah, Jember}

Kegiatan pembacaan asmaul husna adalah kegiatan berdzikir dengan menyebut nama-nama Allah yang berjumlah 99. Biasa dilakukan sebelum KBM dimulai. Pembiasaan kegiatan pembacaan asmaul husna dalam membentuk karakter religius siswa sebagai berikut:

a. Kegiatan pembiasaan pembacaan asmaul husna melatih disiplin dan tanggungjawab dalam menghafal nama-nama Allah untuk menumbuhkan kecintaannya kepada Allah serta agar selalu berusaha serta bertawakal ketika berbuat dosa.

Kegiatan pembiasaan pembacaan asmaul husna dilaksanakan di kelas masing-masing, sebelum kegiatan pembelajaran dimulai. Setelah 


\section{AL-ADABIYAH: Jurnal Pendidikan Agama Islam}

peneliti melakukan kegiatan observasi di MA Darul Hikam kegiatan ini melatih disiplin dan tanggungjawab dalam menghafal nama-nama Allah. Dari kegiatan menghafal ini, kecintaan siswa terhadap Allah Pun mulai tumbuh, serta siswa selalu berusaha serta bertawakal ketika berbuat dosa.

b. Melalui kegiatan pembiasaan pembacaan asmaul husna siswa dilatih untuk senantiasa berdzikir dengan menyebut nama-nama Allah yang berjumlah 99 agar siswa lebih mengenal serta memahami nama-nama Allah sehingga hidup akan terkondisikan untuk selalu beribadah.

Kegiatan pembiasaan pembacaan asmaul husna di MA Darul Hikam melatih siswa untuk berdzikir dengan menyebut nama-nama Allah yang berjumlah 99, dzikir disini merupakan aktivitas ibadah untuk mengingat Allah, mudah dibaca, ringan diaplikasikan ke anak-anak. Dengan diadakannya pembiasaan dzikir asmaul husna sebelum KBM gar siswa lebih mengenal nama-nama Allah sehingga mereka terkondisikan untuk selalu beribadah kepada-Nya.

Temuan ini sesuai dengan pendapat Fadli Ramadan yang mengatakan pentingnya kegiatan pembacaan asmaul husna itu terdapat beberapa alasan utama diantaranya sebagai berikut:

1) Lebih mengenal Allah. Dengan kita mengenal serta memahami nama nama serta sifat-sifat Allah, maka kita sebagai seorang hamba tentu akan bertambah kecintaan kita kepada Allah, selalu berusaha serta tawakal ketika berbuat dosa.

2) Hidup akan terkondisikan untuk beribadah. Memahami Allah dengan mengenal nama-nama serta sifat-Nya merupakan salah satu dasar keimanan seorang hamba. Dengan ini maka keimanan seorang hamba meningkat. Ketika keimanan meningkat, maka ia semakin rajin dalam beribadah kepada Allah.

3) Ilmu mengenai sifat-sifat Allah merupakan ilmu yang paling mulia, serta paling utama. Ilmu ini memiliki tempat kedudukan yang agung serta derajatnya paling tinggi (Ramadan, 2019: 89-90).

\section{Pembiasaan kegiatan khatmil Qur'an dalam membentuk karakter religius di MA Darul Hikam Kertonegoro, Jenggawah, Jember}

Kegiatan khatmil Qur'an adalah kegiatan mengkhatamkan Al-Qur'an dari surah Al-Fatihah sampai surah An-nas. Kegiatan rutinan ini dilaksanakan di MA Darul Hikam setiap dua minggu sekali dan tepatnya di hari senin. 


\section{AL-ADABIYAH: Jurnal Pendidikan Agama Islam}

Pembiasaan kegiatan khatmil Qur'an dalam membentuk karakter religius sebagai berikut:

a. Kegiatan khatmil Qur'an melatih kerjasama melalui pembagian juz Al-Qur'an agar siswa tekun/gemar membaca Al-Qur'an

Pelaksanaan kegiatan khatmil Qur'an rutin diadakan di MA Darul Hikam setiap dua minggu sekali. Setelah peneliti melakukan observasi, kerjasama antara siswa sangat terlihat, karena siswa memiliki keterbatasannya masing-masing, seperti halnya kelancaran dalam membaca al-Qur'an maka dari itu pembina khatmil Qur'an bersama pengurus osis mencoba mengatasi permasalah tersebut agar dapat mencapai tujuan yang diinginkan yaitu dengan melakukan pembagian juz yakni satu siswa membaca satu juz, bagi siswa yang kurang lancar dalam membaca AlQur'an mereka berbagi juz dengan siswa yang lancar membacanya.

Hasil temuan ini sesuai dengan pendapatnya Soerjono Soekanto yang terdapat dalam jurnalnya Yosep Efendi (Efendi, 2018) yang menyatakan bahwa "kerjasama merupakan suatu usaha bersama antara orang perorangan atau kelompok untuk mencapai tujuan tertentu." Dengan diadakannya kerjasama pembagian juz Al-Qur'an, siswa merasa lebih terbantu dan lebih ringan dalam mengemban tugas mengkhatamkan AlQur'an serta dari pembiasaan kegiatan ini siswa menyadari bahwa mereka lebih baik dalam membaca Al-Qur'an baik dari makharijul huruf serta tajwidnya serta tekun/gemar membaca Al-Qur'an.

b. Kegiatan khatmil Qur'an membentuk karakter siswa secara islami

Melalui kegiatan khatmil dapat membentuk karakter siswa untuk memiliki karakter islami, sehingga peserta didik akan menjadi lebih baik lagi dalam bidang keagamaan. Karena di MA Darul Hikam peserta didik terbiasa melakukan khataman Qur'an dengan rutin, sehingga siswa akan memiliki karakter dan berjiwa islami.

Hasil temuan sesuai dengan pendapat Khon (2013: 1) yang menyatakan membaca Al-Qur'an adalah membaca Firman-firman Tuhan dan berkomunikasi dengan Tuhan, maka seseorang yang membaca AlQur'an seolah-olah berdialog dengan Tuhan. Peserta didik dalam mengikuti kegiatan khatmil Qur'an tentu sering melantunkan ayat-ayat Al-Qur'an dengan itu akan menjadikan siswa memiliki jiwa yang islami. Pasalnya dengan membaca Al-Qur'an merupakan bentuk untuk membaca firman- 
firman Allah dengan itu siswa akan merasakan kenyamanan dan ketenangan, sehingga siswa memiliki jiwa islami.

\section{Pembiasaan kegiatan pembelajaran terjemah Al-Qur'an dalam membentuk karakter religius di MA Darul Hikam Kertonegoro, Jenggawah, Jember}

Pembiasaan kegiatan pembelajaran terjemah Al-Qur'an merupakan program unggulan di MA Darul Hikam, pembelajaran terjemah Al-Qur'an disini menggunakan metode PPTQ Safinda yang rutin dilaksanakan setiap hari kecuali hari senin-jum'at, sebelum KBM dimulai. Pembiasaan kegiatan pembelajaran terjemah Al-Qur'an dalam membentuk karakter religius diantaranya sebagi berikut:

a. Melalui kegiatan pembelajaran terjemah Al-Qur'an, siswa lebih cermat dan seksama dalam mempelajari Al-Qur'an sehingga siswa lebih mantap membaca serta menghafal ayat-ayat yang mudah bagi siswa.

Kegiatan pembelajaran terjemah Al-Qur'an disini melatih siswa lebih cermat dan seksama dalam mempelajari Al-Qur'an. Hal tersebut sesuai dengan hasil observasi dan wawancara peneliti bahwa ketika pembelajaran terjemah Al-Qur'an dengan menggunakan metode PPTQ Safinda berlangsung, selain siswa mencermati makna dari ayat Al-Qur'an mereka juga mencermati dengan seksama kedudukan nahwu (isim, fiil dan huruf) serta shorofnya. Kecermatan siswa tidak hanya terlohat ketika pelakasanaan pembelajaran terjemah Al-Qur'an saja, ketika pembelajaran agama berlangsung dikelas seperti akidah akhlak, qurdits, fiqih dan tarikh yang terdapat ayat-ayat Al-Qur'an mereka lebih cermat dan teliti dalam menerjemah ayat-ayat Al-Qur'an. Dari kegiatan pembiasaan ini siswa lebih mantap membaca serta menghafal ayat-ayat Al-Qur'an.

b. Melalui kegiatan pembelajaran terjemah Al-Qur'an, siswa lebih bersungguhsungguh dalam mempelajari Al-Qur'an serta menerjemah Al-Qur'an sehingga mereka mampu memahami kitab Allah dan mampu memperbaiki tingkah laku dalam kehidupan sehari-hari.

Kegiatan pembelajaran terjemah Al-Qur'an disini melatih siswa untuk sungguh-sungguh dalam mempelajari/menerjemah Al-Qur'an, mereka sadar bahwa Al-Qur'an merupakan kalam Allah yang diturunkan kepada nabi Nabi Muhammad melalui malaikat Jibril, oleh sebab itu mereka termotivasi untuk belajar sungguh-sungguh. Dari kesungguhan siswa dalam menerjemah Al- 


\section{AL-ADABIYAH: Jurnal Pendidikan Agama Islam}

Qur'an tersebut mereka mampu memahami Al-Qur'an serta mampu memperbaiki tingkah lakunya dalam kehidupan sehari-hari.

Hasil temuan ini sesuai dengan pendapat Tim Perumus dalam bukunya yang berjudul Metodologi Pengajaran Agama yang dikutip oleh Sri Belia Harahap menyatakan dalam proses pembelajaran Al-Qur'an memiliki tujuan sebagai berikut yaitu memberikan pengetahuan Al-Quran kepada anak yang mampu mengarahkan kepada:

1) Kemantapan membaca sesuai dengan syarat-syarat yang telah ditetapkan dan menghafal ayat-ayat atau surat-surat yang mudah bagi mereka

2) Kemampuan memahami kitab Allah secara sempurna, memuaskan akal dan mampu menenangkan jiwanya

3) Kesanggupan menerapkan ajaran Islam dan menyelesaikan problema hidup sehari-hari

4) Kemampuan memperbaiki tingkah laku murid melalui metode pengajaran yang tepat

5) Kemampuan memanifestasikan keindahan retorika dan uslub Al-Qur'an

6) Penumbuhan rasa cinta dan keagungan Al-Qur'an dalam jiwanya.

7) Pembinaan pendidikan Islam berdasarkan sumber-sumbernya yang utama dari Al-Qur'an (Harahap, 2020: 16).

\section{Kesimpulan}

Pembiasaan kegiatan sholat dhuha dalam membentuk karakter religius di MA Darul Hikam Kertonegoro Jenggawah Jember adalah ketepatan waktu, berjama'ah dan khusyuk dalam menjalankan ibadah. Pembiasaan kegiatan pembacaan asmaul husna dalam membentuk karakter religius di MA Darul Hikam Kertonegoro Jenggawah Jember adalah membiasakan siswa untuk berdzikir, disiplin dan tanggung jawab dalam menghafal nama-nama Allah. Pembiasaan kegiatan khatmil Qur'an dalam membentuk karakter religius di MA Darul Hikam Kertonegoro Jenggawah Jember adalah kerjasama melalui pembagian juz dan membiasakan siswa untuk tekun membaca Al-Qur'an. Pembiasaan kegiatan pembelajaran terjemah Al-Qur'an dalam membentuk karakter religius di MA Darul Hikam Kertonegoro Jenggawah Jember adalah kesungguhan dan ketelitian siswa dalam menerjemah Al-Qur'an sehingga mereka mampu memahami kitab Allah dan mampu memperbaiki tingkah lakunya dalam kehidupan sehari-hari. 


\section{Referensi}

Andri Kautsar dan Johan Edi, "Pendidikan Karakter Religius, Disiplin Dan Bakat Melalui Penigkatkan Kualitas Sarana Prasarana Sekolah", JMKSP Jurnal Manajemen, Kepemimpinan, dan Supervisi Pendidikan Volume 2, NO.2, (JuliDesember 2017): 254-278

Ardy Wiyani, Novan. "Pengembangan Program Kegiatan Pembiasaan TQM di Raudhatul Athfal (RA)", Jurnal Pendidikan Anak, vol. 3 no. 1 (Februari 2017), $1-20$

Atika, Surya. "Pelaksanaan Pendidikan Karakter (Religius, Cinta Tanah Air Dan Disiplin) Di Slb Al Ishlaah Padang”, Jurnal Ilmiah Pendidikan Khusus Volume 3, No. 3, (September 2014): 747-755

Bekti Wulandari, Fatchul Arifin, Dessy Irmawati, "Peningkatan Kemampuan Kerjasama dalam Tim melalui Pembelajaran Berbasis Lesson Study", Jurnal Electronic, Informance, And Vovational Education (ELINVO), vol. 1, no. 1 (November 2015), 9-16

Bungaran Antonius Simanjuntak dan Soedjito Sosrodiharjo. Metode Peneltian Sosial. Jakarta: Yayasan Puataka Obor Indonesia, 2014

Dalyono, M. Psikologi Pendidikan. Jakarta: Rineka Cipta, 2010.

Depdiknas. kamus bahasa indonesia pusat bahasa. Jakarta: PT. Gramedia Pustaka, 2008.

Efendi, Yosep. Penguatan Karakter Mandiri, Disiplin, Kerjasama Dan Kreatif ("Marikerja Kreatif) Melalui Lesson Study Pada Pembelajaran Teknologi Sepeda Motor" jurnal pendidikan vokasi otomotif, vol. 1 no.1, (November 2018): 89-99

Fathurrohman, Muhammad. Budaya Religius Dalam Peningkatan Mutu Pendidikan: Tinjauan Teoritik Dan Praktik Kontekstualisasi

Harahap, Sri Belia. Strategi Penerapan Metode Ummi Dalam Pembelajaran AlQur'an. Surabaya: Scopindo Media Pustaka, 2020

Khon, Abdul Majid. Praktikum Qira'at Keanehan Bacaan Al-Qur'an Qira'at Ashim Dari Hafash. Jakarta: Amzah, 2013.

Koesworo, Ucu. "Belajar Matematika Menggunakan Software Geogebra Classic Versi 5.0 Dalam Membuat Grafik Pada Materi Fungsi Kuadrat, Jurnal Edukasi Sebelas April, vol. 2 no. 1, (Februari 2018): 1-7

Latifah, Imro'atul. “Implementasi Metode Pembiasaan Keagamaan dalam Membentuk Karakter Religius Siswa Madrasah Tsanawiyah NU Darussalam Ngadirgo Mijen Semarang." Skripsi, UIN Walisongo Semarang, 2018. 


\section{AL-ADABIYAH: Jurnal Pendidikan Agama Islam}

M. Junaidi Ghony dan Fauzan Almanshur. Metodologi Penelitian Kualitatif. Yogyakarta: Ar-Ruzz Media, 2012.

Miles, Huberman and Saldana. Qualitative Data Analysis. America: SAGE Publication, 2014.

Moleong, Lexy J. Metodologi Penelitian Kualitatif . Bandung: PT Remaja Rosdakarya, 2017

Prasetyo, Eko Budi "Implementasi Pembiasaan Nilai-Nilai Asmaul Husna Di SMAN 2 Kota Serang Dalam Pembentukan Karakter Religius Siswa", Universitas Pendidikan Indonesia, repository.Upi.edu, perpustakaan.upi.edu(2017): 1-8

Ramadan Fadli. Dzikir Pagi Dan Petang. Yogyakarta: Fillah Book, 2019.

Rosidatun. Model Implementasi Pendidikan Karakter. Gresik: Caremedia Communication, 2018.

Sahlan, Asmaun. Religiusitas Perguruan Tinggi: Potret Pengembangan Tradisi Keagamaan Di Perguruan Tinggi Islam. Malang: UIN-Mliki Press, 2012.

Sekretariat Negara RI, Undang-undang No. 20 tahun 2003 tentang Sistem Pendidikan Nasional

Sugiyono. Metode Penelitian Kuantitatif, Kualitatif dan $R \& D$. Bandung: Alfabeta, 2016

Wibowo, Agus. Pendidikan Karakter. Jakarta: Pustaka Pelajar, 2012.

Wuryanano, Super Mind For Successful Life (Cara Merancang Kehidupan yang Penuh Kebahagian dan Kesuksesan).Jakarta: PT Elex Media Komputindo, 2004 